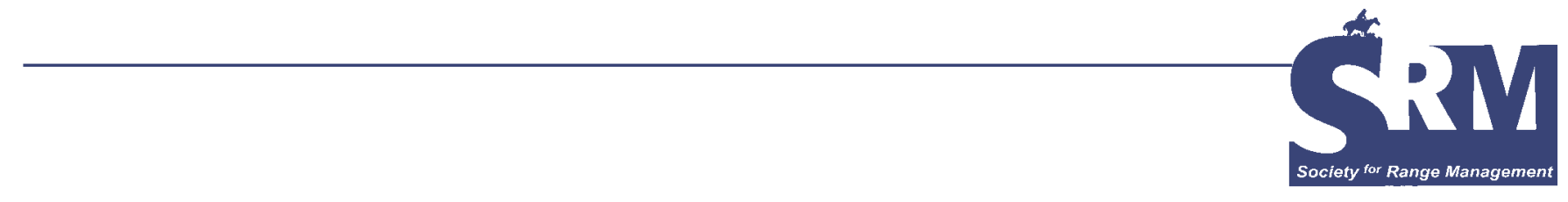

\title{
Monitoring Heifer Grazing Distribution at the Valles Caldera National Preserve
}

\section{By Andrés F. Cibils, Joshua A. Miller, A. Manuel Encinias, Kenneth G. Boykin, and Brad F. Cooper}

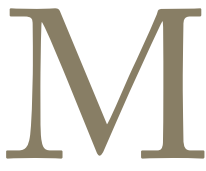

anipulating livestock grazing patterns on rangelands continues to be a major challenge for range managers throughout the western United States. ${ }^{1}$ This is especially true at the Valles Caldera National Preserve where rangeland management is tailored to meet the needs and expectations of a variety of stakeholders. The preserve was established by the Valles Caldera Preservation Act of 2000 (VCPA), and covers 36,000 ha of picturesque landscape. The preservation act stipulates that the preserve be operated as a working ranch while preserving its resources in the context of multiple land use and sustained yield (VCPA sec. 108 [d]). This makes the Valles Caldera a unique national preserve that is managed in a way that creates opportunities to "conduct research on new ranching techniques to determine their efficacy in both maintaining and improving rangeland" (p. 57). ${ }^{2}$

Most of the Valles Caldera lies within a collapsed volcanic field that resembles a gigantic bowl approximately $22 \mathrm{~km}$ in diameter surrounded by a rim of forested mountains. These landscape features cause the Valles Caldera to function as a self-contained watershed with almost all headwaters of the $43 \mathrm{~km}$ of streams meandering through the valley bottoms being located within the boundaries of the preserve ${ }^{2}$ (Fig. 1). Consequently, changes in the quality of water that flows out of Valles Caldera riparian corridors to the Jemez River can be traced back to events (either natural or management-induced) within the preserve.

Approximately 2,000-2,500 elk, ${ }^{3}$ in addition to fishermen and cattle, use the preserve's riparian corridors and streams; thus, considerable effort is being expended to develop strategies to preserve these areas. Among riparian users, yearling cattle have earned a reputation of overstaying their welcome, causing preserve managers to establish a proactive program to manipulate cattle distribution. Tubs containing low-moisture molasses and 36\% crude protein supplement (Ridley Inci) and salt blocks were placed away from streams and valley bottoms. This combined with noontime herding were used to lure first calf heifers away from riparian habitats.

Management of livestock using riparian areas has long been a major concern of rangeland managers throughout the western United States. ${ }^{4}$ Strategies that involve light to moderate livestock grazing typically do not negatively affect riparian habitats ${ }^{5}$ however, improper livestock grazing detrimentally affects streamside vegetation and can eventually compromise stream bank stability, triggering erosional processes altering stream hydrology and aquatic life. ${ }^{4}$ The management strategies tested by the preserve management (supplements + herding) were suggested as means to change cattle foraging habits and regulate their use of riparian habitats. $^{4}$

A number of experiments conducted prior to this case study have successfully used strategically placed supplements and herding. However, the studies on which this management strategy is based used mother cows during the winter or fall months when forages are typically dormant. ${ }^{6-8} \mathrm{We}$ do not know whether these same strategies are effective for changing the grazing habits of yearling heifers, which are known to use landscapes differently than adult cows, ${ }^{9}$

Crystalyx ${ }^{\circledR}$ http://www.crystalyx.com/. 


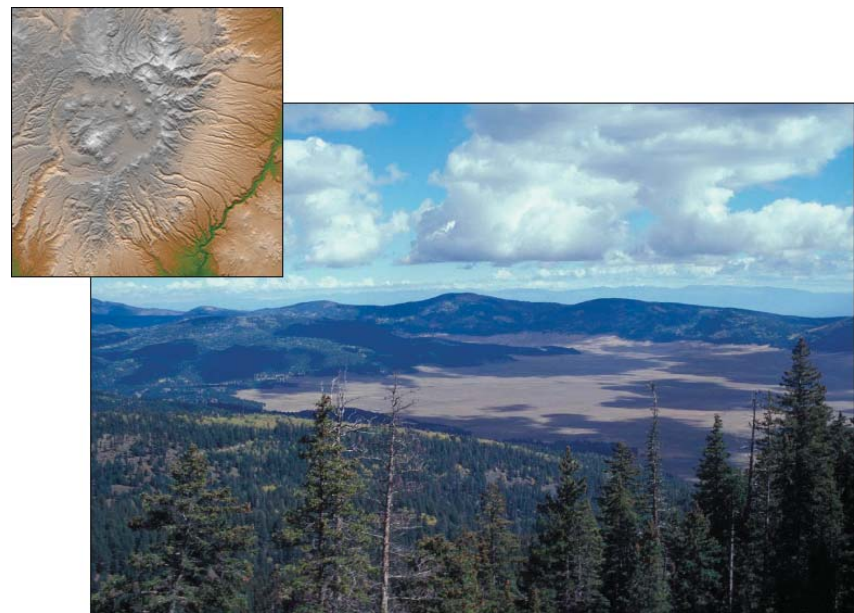

Figure 1. Panoramic view of the Valles Caldera National Preserve (VCNP; photo credit: Robert R. Parmenter, VCNP) and NASA satellite image of the VCNP and surrounding Jemez Mountains.

or whether they would work during summer when the nutritional value of forages is usually better. Furthermore, it was unclear whether these management prescriptions would be effective for working ranches like the Valles Caldera preserve.

\section{Tracking Heifer Movements}

During the 2004 and 2005 grazing seasons (1 June30 September) preserve managers put in place a progressive heifer development program. This program included offering fee-based grazing to New Mexico livestock producers via a lottery system. Each year, multiple producers participated by contributing three to 20 or more animals to a herd totaling approximately 600 first-calf heifers. Grazing capacity of valley areas was estimated at approximately 2,000 animal units for the grazing season. Thus, pastures were very lightly stocked both summers. Heifers included in the program had never grazed the Valles Caldera before, and had been raised in contrasting environments (feed lots, irrigated pastures, rangelands), which provided the additional opportunity to document distribution patterns of same-age animals with vastly different early life experiences.

Tubs of supplement and salt blocks were placed in upland locations approximately 500-1,900 m (0.3-1.2 miles) from the valley bottoms at the beginning of each grazing season. Supplements were expected to provide a reward luring cattle from riparian areas into underutilized uplands. Herbaceous biomass of riparian sites was in some instances twice that of upper grazed woodlands. ${ }^{10}$ In addition, Monday through Saturday, riders mounted on horseback would push cattle away from the streams into the direction of the closest tub of supplement. Two days each week, riders would herd groups of cattle all the way to the tubs (all heifers were assumed to be initially unfamiliar with the supplement); whereas once a week, cattle were not herded and were allowed to graze freely in the pasture. In all cases herding was conducted at midday after cattle had access to water.

Eighteen heifers (nine each year) were fitted with collars equipped with global positioning systems (GPS; Lotek 3300) programmed to acquire and record animal location at 5 -min (in 2004) or 15-min (in 2005) intervals. Collars were evenly distributed among Beefmaster heifers that were raised in either a feed lot, on irrigated pastures, or on rangeland. Three heifers from each environment were tracked for $24 \mathrm{~h}$ throughout the grazing season. GPS data were downloaded monthly, differentially corrected (a process that increases data precision to within 3-5 m), and mapped onto a digital orthophotograph. Location of tubs of supplement, salt blocks, and perennial streams were also mapped (Fig. 2). A 250-m (820-foot) area around East Jemez and Jaramillo streams (main permanent streams on the preserve) and tubs of supplement (salt blocks were not mapped) were mapped to determine the amount of time heifers spent close to streams and tubs of supplement. An additional 20-m (66-foot) area was generated around streams to determine time spent in the proximity of stream banks. Statistical analyses of cattle location in each pasture (Valle Grande and Jaramillo) were conducted to answer the following questions: 1) is supplement and salt placement away from streams in addition to herding an effective strategy to manage riparian habitats?; 2) is this an effective tool for working ranches?; and 3 ) is the selection of animals with prior knowledge of rangeland environments an effective tool to reduce utilization of riparian areas?

\section{Streamside Amenities vs. Protein Supplements}

Efforts to modify feeding habits of heifers were only partially successful. Grazing distribution differed slightly between pastures; however, heifers spent less than $1 \mathrm{~h}$ per day within $250 \mathrm{~m}$ of supplement-filled tubs, regardless of previous environmental experiences (Fig. 3). Moreover, increasing time spent close to tubs on any given day did not necessarily translate into less time spent in the proximity of streams as we had predicted (Fig. 3).

Heifers spent, on average, about $1 \mathrm{~h}$ per day within $20 \mathrm{~m}$ of both the East Jemez and Jaramillo stream banks, and approximately $9 \mathrm{~h}$ per day within $250 \mathrm{~m}$ of these streams (Fig. 4). About two-thirds of total time spent in the proximity of main streams occurred during daylight hours (Fig. 4).

Use of the Valles Caldera did not differ between rangeland-raised heifers and their peers raised in feedlots. The number of animals being tested was small and larger herd dynamics likely overwhelmed any prior influence as the heifers adapted to the new social and environmental conditions. All groups, however, showed inconsistent patterns of streamside utilization. This phenomenon was most apparent in heifers that had been raised on irrigated pastures, which were the group that spent both the least 


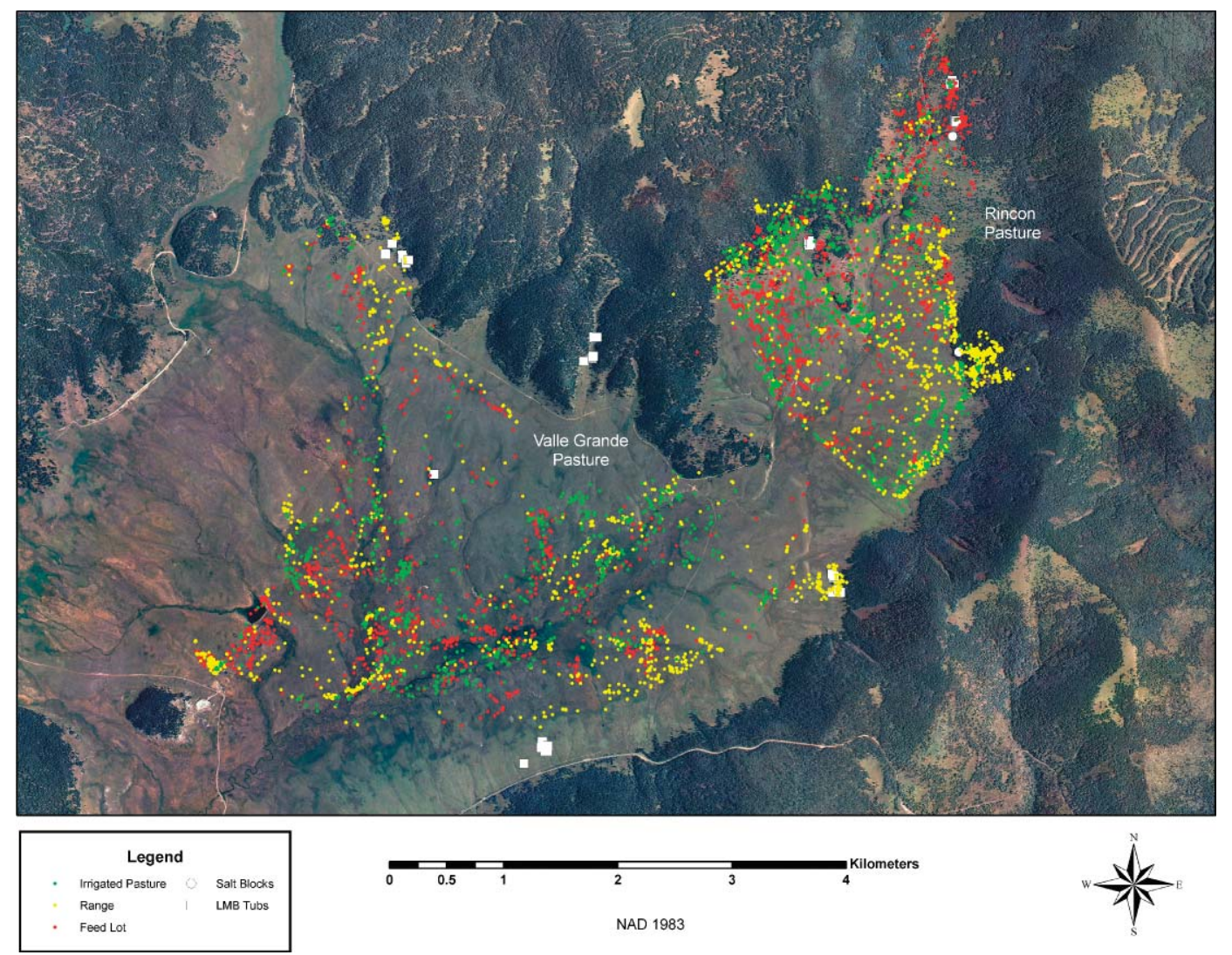

Figure 2. Locations of three global positioning system-collared heifers recorded at 15-min intervals during the 2005 grazing season. Yellow points correspond to heifers that were raised on rangeland, green points to heifers raised on irrigated pastures, and red points correspond with heifers raised in a feedlot. White squares and circles show the location of tubs of supplement (LMB) and salt blocks, respectively. East Jemez and Jaramillo are the main streams that can be seen in this 2005 digital orthophotograph of the Valle Grande and Rincon pastures.

(Rincon) and most (Valle Grande) time close to streams (Fig. 3). Interestingly, all heifers spent a similar (and very small) amount of time within $250 \mathrm{~m}$ of the tubs that were placed in both pastures (Fig. 3).

\section{Would Herding Alone Get the Job Done?}

Strategically placed tubs with low-moisture supplements were successfully used to modify grazing distribution of mature cows in Montana. ${ }^{6-8,11,12}$ In most cases, tubs and some degree of herding were used during either the fall or winter. A recently published study, ${ }^{12}$ using herding and tubs with low-moisture molasses and protein supplement during the summer, described a situation where cattle spent approximately $5 \mathrm{~h}$ per day within $100 \mathrm{~m}$ (328 feet) of perennial streams (a result that is comparable to ours), but spent about $2 \mathrm{~h}$ per day within $200 \mathrm{~m}$ (656 feet) of upland areas where tubs and salt were placed. In our study, heifers spent less than $1 \mathrm{~h}$ within a similar distance of the tubs. Interestingly, in the Montana study, ${ }^{12}$ cows that were herded to uplands during the summer without tubs of supplement and salt attractants spent a similar amount of time close to perennial streams, as did herded cows in pastures with tubs of supplement and salt in upland areas. Our observations are in partial agreement with the findings of this Montana study ${ }^{12}$ that suggests herding may be more critical than upland placement of tubs of supplement as a means of reducing the time yearling heifers spend in sensitive riparian areas during the summer.

It is worth noting that grasses at the Valles Caldera can be quite nutritious relative to other rangeland forages, with crude protein values above $12 \%$ and digestibility in excess of $60 \% .{ }^{13}$ It seems reasonable to speculate that when cattle graze unrestricted amounts of high-quality forage (as was apparently the case in both seasons at the Valles Caldera) they lose their motivation to consume supplements and any incentive to remain in the proximity of tub locations.

In our study, prior environmental experiences of heifers did not influence their spatial use of pastures containing riparian vegetation. Because the nine heifers studied each year grazed along with a diverse herd of 600 heifers, it is possible that peer influences overrode any previously acquired behavioral tendencies. The fact that we did observe some differences among groups supports previous reports indicating that cattle vary in their use of riparian habitats. ${ }^{14}$ 
Rincon

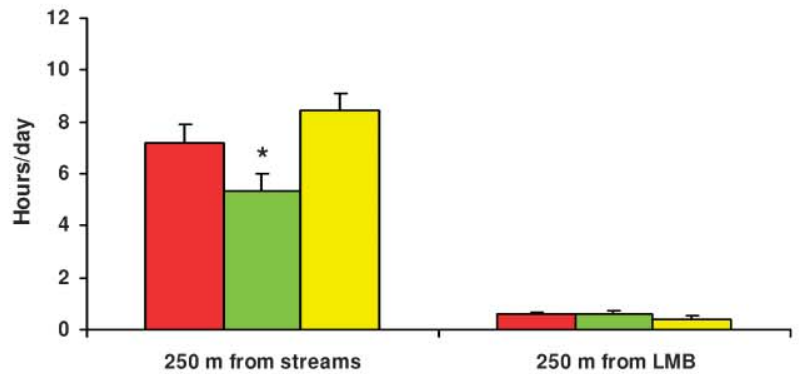

Rincon

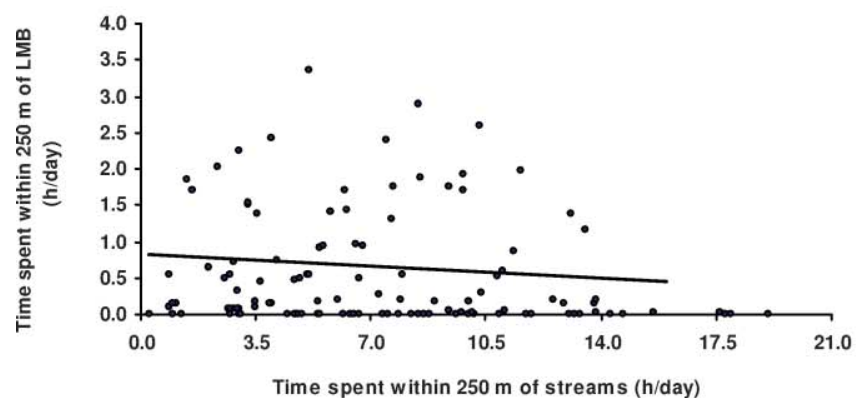

Valle Grande

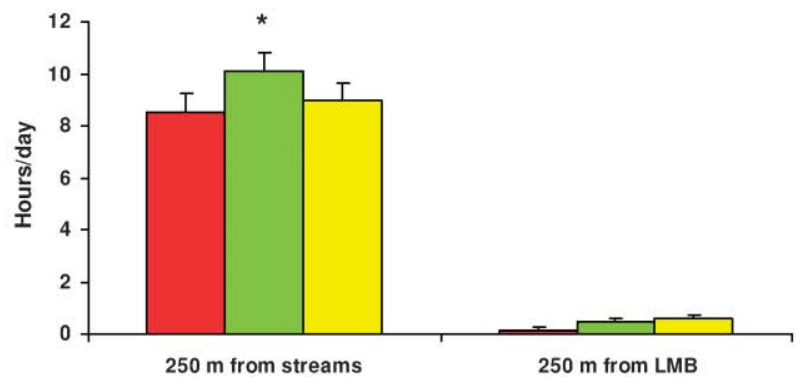

Valle Grande

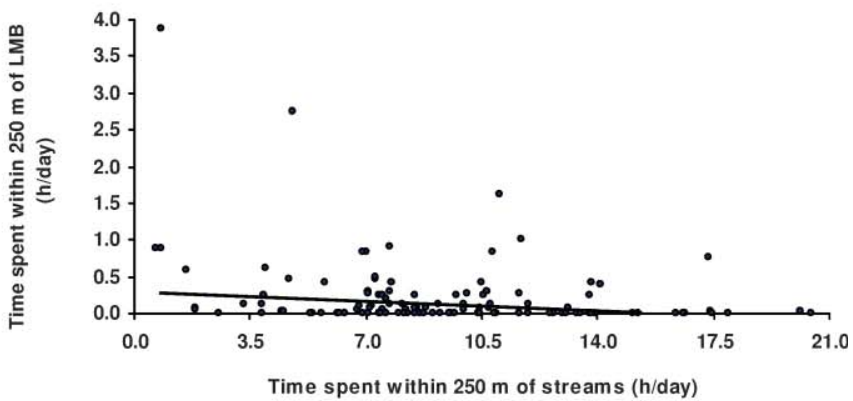

Figure 3. Daily time spent by collared heifers $(n=18)$ raised on rangeland (yellow bars), irrigated pastures (green bars), and feed lot (red bars), within $250 \mathrm{~m}$ (820 feet) of perennial streams and tubs of supplement (LMB) in Rincon (upper left) and Valle Grande (upper right) pastures. Error bars show standard error of means and asterisks indicate statistically detectable difference at a 5\% probability level. Lower panels show the relationship between daily time spent within 250 m of LMB and streams in Rincon (lower left) and Valle Grande (lower right) pastures. Curves show lack of statistically detectable relationship between these two variables.

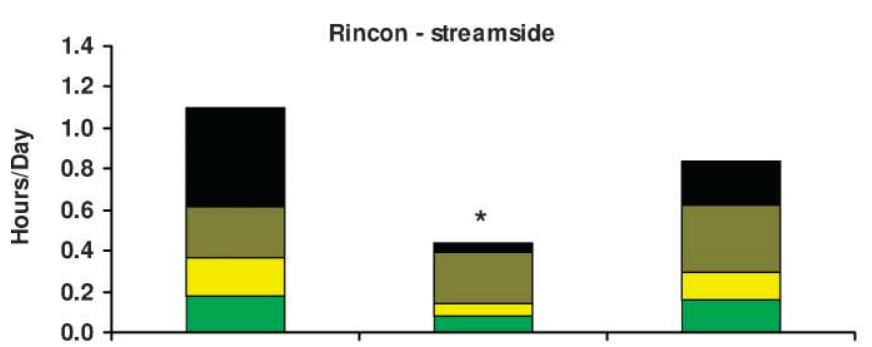

Rincon - $250 \mathrm{~m}$ from streams

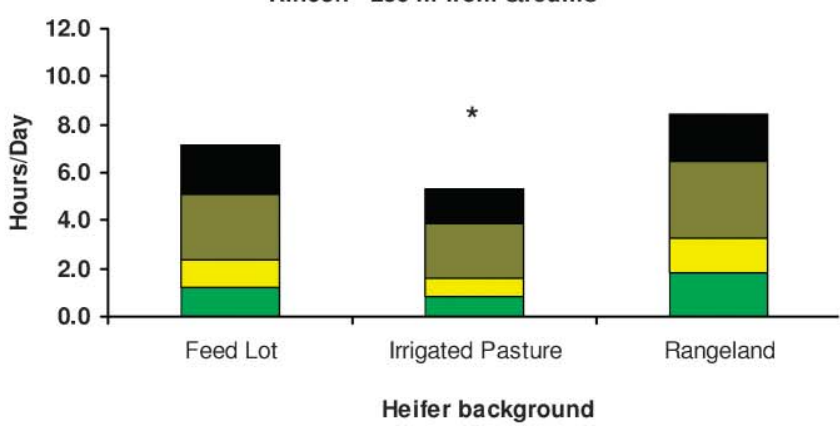

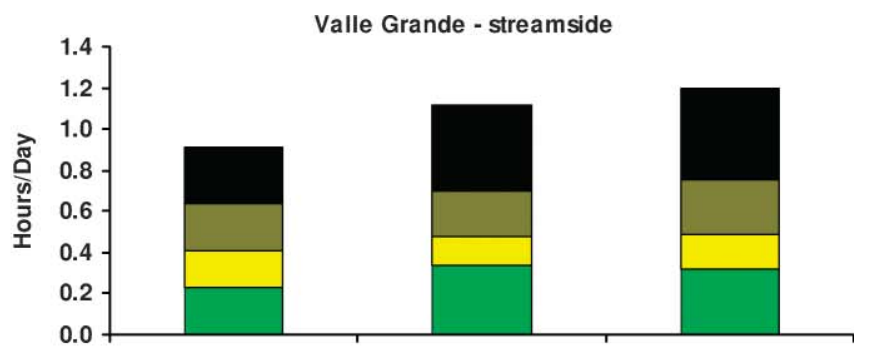

Valle Grande - $250 \mathrm{~m}$ from streams

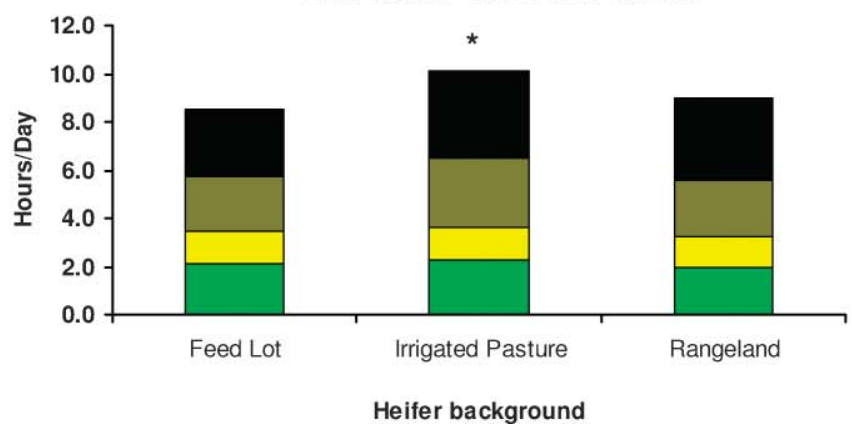

Figure 4. Daily time spent by collared heifers $(n=18)$ with different backgrounds within $20 \mathrm{~m}$ and $250 \mathrm{~m}$ (66 feet and 820 feet) of perennial streams in Rincon (left) and Valle Grande (right) pastures. Stacked bars indicate hours during morning (bright green; 5:00-10:59 AM), noon (yellow; 11:00 AM-2:59 PM), afternoon (olive green; 3:00-8:59 PM), or night (black; 9:00 PM-4:59 AM) spent within 20 m and $250 \mathrm{~m}$ of streams. 


\section{References}

1. Holechek, J. L., R. D. Pieper, and C. H. Herbel. 2004. Range management principles and practices. 5th ed. Upper Saddle River, NJ, USA: Prentice Hall. 607 p.

2. Valles Caldera Trust. 2003. Valles Caldera National Preserve: framework and strategic guidance for comprehensive management. $187 \mathrm{p}$.

3. Kohlman, S. G. 2006. A synopsis of elk population data and some management suggestions for the Valles Caldera $\mathrm{Na}-$ tional Preserve. Available at: http://www.caldera-action.org/ A-documents/Related\%20Documents/elk_management.htm. Accessed 14 August 2008.

4. US Department of the Interior. 2006. Riparian area management: grazing management processes and strategies for riparian-wetland areas. Denver, CO, USA: Bureau of Land Management, National Science and Technology Center. Technical Reference 1737-20. BLM/ST/ST-06/002+1737. $105 \mathrm{p}$.

5. Elmore, W., and B. Kauffman. 1994. Riparian and watershed systems: degradation and restoration. In: M. Vavra, W. A. Laycock, and R. D. Pieper [EDS.]. Ecological implications of livestock herbivory in the West. Denver, CO, USA: Society for Range Management. p. 212-231.

6. Bailey, D. W., and G. R. Welling. 1999. Modification of cattle grazing distribution with dehydrated molasses supplement. Journal of Range Management 52:575-582.

7. Bailey, D. W., G. R. Welling, and E. T. Miller. 2001. Cattle use of foothills rangeland near dehydrated molasses supplement. Journal of Range Management 54:338-347.

8. Bailey, D. W., and G. R. Welling. 2007. Evaluation of lowmoisture blocks and conventional dry mixes for supplementing minerals and modifying cattle grazing patterns. Rangeland Ecology and Management 60:54-64.

9. Launchbaugh, K. L., And L. D. Howery. 2005. Understanding landscape use patterns of livestock as a consequence of foraging behavior. Rangeland Ecology and Management 58:99-108.

10. Slaughter A., and B. Nolen. 2007. Valles Caldera National Preserve May, 2007 standing biomass data. Available at: http://usda-ars.nmsu.edu/data-info/VCNPData/ VCNPUtilMapMay07.pdf. Accessed 14 August 2008.

11. Thrift, T. M., T. K. Brewer, and G. R. Welling. 2007. Low-moisture blocks: a tool to promote uniform utilization by cattle? Rangelands 29:37-40.

12. Bailey, D. W., H. C. Van Wagoner, R. Weinmeister, and D. Jensen. 2008. Evaluation of low-stress herding and supplement placement for managing cattle grazing in upland and riparian areas. Rangeland Ecology and Management 61:26-37.

13. Parmenter, R. R. 2006. Range readiness analysis for VCT livestock program for summer 2006. Available at: http://www. vallescaldera.gov/ranching/grazing/2006RangeReadinessFinal. pdf. Accessed 14 August 2008.

14. Howery, L. D., F. D. Provenza, R. E. Banner, and C. B. Scotт. 1996. Differences in home range and habitat use among individuals in a cattle herd. Applied Animal Behavior Science 49:305-320.

Authors are Assistant Professor of Range Science, acibils@nmsu. edu (Cibils), Extension Livestock Specialist (Encinias), Ecologist (Boykin), and Undergraduate Range Science student (Cooper), New Mexico State University, Las Cruces, NM 88003, USA; and Rangeland Management Specialist, USDA-Natural Resources Conservation Service, Deming, NM 88030, USA (Miller). This project was funded by the New Mexico Agricultural Experiment Station and the USDA CSREES Rangeland Ecosystems Project and by a grant from Ridley Blocks Inc. to A. M. Encinias. 